\title{
Technical and economic evaluation of energy production from wind in Istanbul and surrounds
}

\author{
Ali Vardar* \\ Onur Taşkin \\ Department of Biosystems Engineering, Faculty of Agriculture, Uludag University, Görükle Campus, Nilüfer, \\ Bursa, Turkey
}

\begin{abstract}
Istanbul is located in the northwest part of Turkey and has the greatest population of any city in the country. Istanbul and its surroundings were researched for wind potential. Energy production from wind was evaluated technically and economically in this study. Çorlu, Kumköy and Sile sites were examined. Other sites in the same region (Göztepe, Kireçburnu, Bahçeköy, Florya and Kartal) were also evaluated but the results were not satisfactory, and for this reason, these sites were not examined in this study. When we checked daily, monthly and yearly wind speed values and frequency distributions, the wind energy potential of Çorlu, Kumköy and Şile were greater than other sites. Çorlu, Kumköy and especially Şile's wind speed data are statistically decreasing. A Nordex N117 91m hub height wind turbine can produce 6099 MWh in Çorlu, 6459 MWh in Şile, 7265 MWh in Kumköy. A Nordex N117 140 m hub height wind turbine can produce $6471 \mathrm{MWh}$ in Çorlu, 7439 MWh in Sile and 8175 MWh in Kumköy. The energy costs were calculated by the average of 36 years of wind measurement data using Nordex N117 turbines. Energy costs with Nordex N117 $91 \mathrm{~m}$ and $140 \mathrm{~m}$ hub height in Çorlu, Şile and Kumköy are 0.025-0,027 US\$/KWh, 0.022-0,025 US\$/KWh, 0.020-0,023 US $\$ / K W h$, respectively.
\end{abstract}

Keywords: wind potential, energy production, energy cost, pay-back period

Corresponding author. Tel: 02242941605

Email:dravardar@uludag.edu.tr

dravardar@hotmail.com

\author{
Nomenclature \\ I the investment cost of the wind turbine, the \\ cost of civil works and the connection \\ cables to the grid \\ $\mathrm{n}$ the life expectancy of the wind turbine \\ Com the operation and maintenance costs \\ s the scrap value (10\% of the capital cost \\ excluding the civil construction and cable \\ costs \\ $r \quad$ the discount rate (12\%) \\ $\mathrm{i}$ the inflation rate $(10 \%)$
}

\section{Introduction}

The investment and developments of wind energy have been increasing in recent years. Nowadays, wind energy is the fastest developing sector. The world's installed power capacity of wind energy grew $28.7 \%$ per year between 1998 and2010 and, at the end of 2010, the installed capacity of world was 196630 MW (Anon, 2011a). These rates will continue to increase in the coming years too.

Germany was the leader of installed power capacity until to 2007, and the USA, Spain, India and China followed Germany. But in the past three years (2008-2010), the USA and China made huge investments to wind energy and have joined the race. Today, the installed power capacities of China, USA, Germany and Spain are around 44733 MW, 40180 MW, 27215 MW, 20676 MW, respectively. Wind energy is now supplying $2.5 \%$ of the world's electricity. Germany is one of the developed countries that uses wind energy and it meets $9 \%$ of its electricity needs through wind energy. The rates for Spain, Portugal and Denmark are 16\%, 18\%, 21\%, respectively (Anon, 2011a). When we look at this topic from a Turkish standpoint, its wind energy potential is similar to that of developed countries. Also, it is possible to reach similar rates which other countries have already achieved. 
It is predicted that the world has $53400 \mathrm{TWh} / \mathrm{yr}$ wind energy potential (Orth, 2008). The wind energy potential values of the UK, Spain, Greece and Germany are $114 \mathrm{TWh} / \mathrm{yr}$, 86TWh/yr, $44 \mathrm{TWh} / \mathrm{yr}$, $24 \mathrm{TWh} / \mathrm{yr}$, respectively. It is foreseeable that Turkey has $166 \mathrm{TWh} / \mathrm{yr}$ wind energy potential (Kenisarin et al., 2006). Theoretically, this potential can meet the total electricity demand of Turkey. On the other hand, Turkey's installed power capacity was around 1478 MW in May 2012 (Anon, 2012b). This value shows that Turkey is just using $1.73 \%$ of its wind energy potential. Considering recent global developments and Turkey's wind energy potential, it is possible that Turkey could also join the race to introduce wind energy as a primary source of electricity.

The main factors for global development in the wind energy sector have been high efficiency in the wind power value and new technologies in electricity converters. Therefore, the electricity production costs of wind energy are decreasing. Within this framework, it is necessary to search wind energy sources and locations for economic usage (AlAbbadi, 2005). If investments are built in inefficient locations, it will damage national economies and will not give the desired results. For this reason, wind energy potential, capacity of energy production, wind characteristics and energy production costs should be displayed for each region, and these results will help investors.

For the purposes of this study, wind energy potential and wind characteristics were determined for Istanbul and its surroundings. Energy amount and cost were calculated by using $2.4 \mathrm{MW}$ wind turbines. In addition, the repayment time of investments has been analysed.

\section{Material and methods}

In this study, eight different meteorology sites in Istanbul and its surrounds were examined. The site names were Göztepe, Kumköy, Şile, Bahçeköy, Florya, Kartal and Çorlu. Wind speed data was obtained from the Turkish State Meteorological Service (Anon, 2011c). The wind speed measurements were taken between 1975 and 2010 (36 years in total). General information for the various sites is shown in Table 1. Urban development around the sites was also brought into the scope of research. It is considered that the wind speed data from the 36 year period was affected negatively by urban development. The average of yearly changes in wind speed are shown in this study because negativities affect energy production value, energy production costs and pay-back periods (Figure 1 and Table 2). It was necessary to choose a location where wind turbines will be not affected by these negativities. Legislation prevents urban development around wind energy stations because such development negatively influences wind speed.
Table 1: Summary of daily wind data for 8 locations in Turkey

\begin{tabular}{lcccc}
\hline Location & Latitude $^{a}$ & Longitude $^{a}$ & $\begin{array}{c}\text { Altitude }^{a} \\
(\mathrm{~m})\end{array}$ & $\begin{array}{c}\text { No. of } \\
\text { Records }\end{array}$ \\
\hline Kumköy & $41: 14$ & $29: 03$ & 42 & 314496 \\
\hline Çorlu & $41: 10$ & $27: 48$ & 144 & 313608 \\
\hline Şile & $41: 10$ & $29: 37$ & 16 & 297072 \\
\hline Göztepe & $40: 58$ & $29: 03$ & 11 & 313872 \\
\hline Kireçburnu & $41: 10$ & $29: 04$ & 28 & 306816 \\
\hline Florya & $40: 58$ & $28: 47$ & 31 & 309984 \\
\hline Kartal & $40: 53$ & $29: 11$ & 67 & 293664 \\
\hline Bahçeköy & $41: 11$ & $28: 59$ & 194 & 279048 \\
\hline \begin{tabular}{l} 
a Taken from Google Earth \\
\hline
\end{tabular}
\end{tabular}

Table 2: Relation between years and wind speed $(91 \mathrm{~m})$

\begin{tabular}{lcc}
\hline Location & Equation & $r^{2}$ \\
\hline Şile & $\mathrm{y}=-0,1342 \mathrm{x}+8,5423$ & $\mathrm{R}^{2}=0,9225$ \\
\hline Kumköy & $\mathrm{y}=-0,0506 \mathrm{x}+7,4174$ & $\mathrm{R}^{2}=0,3983$ \\
\hline Çorlu & $\mathrm{y}=-0,0668 \mathrm{x}+6,963$ & $\mathrm{R}^{2}=0,623$ \\
\hline
\end{tabular}

When predicting the level of energy produced, it is important to know the wind speed curve, and how many hours in total does the wind blow in a year. On the other hand, it carries weight with the chosen wind turbine because there is a relationship between cut-in, cut-out, rated, survival wind speed values and the frequency of wind blowing for the chosen wind turbine. Depending on these relationships, the amount of energy production was estimated for the chosen wind turbine. In this study, the frequency of wind blowing was determined. The productivity of these sites was reviewed by using this data.

One of the chosen wind turbine's energy production levels is shown for one of the selected locations in this study. Nordex company models are frequently encountered in wind turbine producers, so the Nordex N117/2400 model was selected. This model has two different (91 m and $140 \mathrm{~m}$ ) hub heights. The technical features of the chosen wind turbines are shown in Table 3. The chosen wind turbine's technical features are cut-in, cut-out speed, rated speed, tip speed, rated output, hub height, rotor diameter and life expectancy. When looking at these features, it is apparent that wind turbines can work between 3-20 ms ${ }^{-1}$ wind speed, and 7.5-13.2 $\mathrm{ms}^{-1}$ rated speed. The tip speed value was $72 \mathrm{~ms}^{-1}$ tip. The rated output value was $2400 \mathrm{~kW}$. The rotor diameter was $116.8 \mathrm{~m}$ and the economic life expectancy was 20 years.

Energy production levels were calculated not only on the basis of the average of the 36 year time period, but also year by year between 1975 - 2010. The wind turbine whose features were listed before 


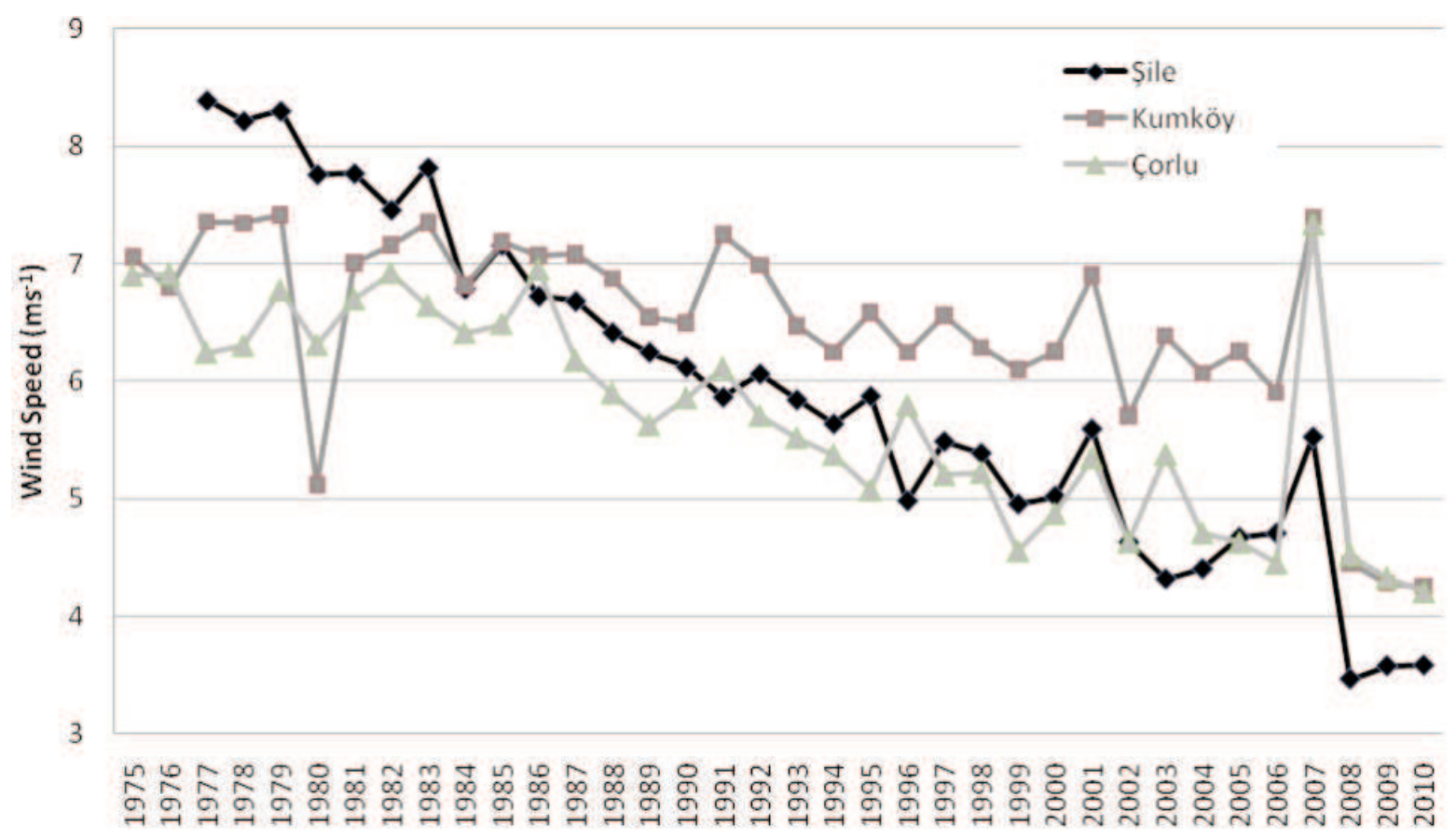

Figure 1: The wind speed value changes on $91 \mathrm{~m}$ hub height of three sites

was used in this prediction. The energy production table was prepared for each site such as seen in Table 4 for the Kumköy site. The wind measurement average of 36 years between 1975-2010 was calculated and the energy production example table of Kumköy was prepared using $91 \mathrm{~m}$ hub heights.

Determining the economics of the wind energy conversion (WEC) system depends mainly on the operator-specific boundary conditions. A simplified approach to calculating the cost of electricity per $\mathrm{kWh}$ takes into account wind system investment costs, operation and maintenance costs, including the WEC costs, foundation, grid connection, planning and licensing. The operation and maintenance costs include repair, insurance, monitoring and management, while the capital costs consist of interest and loan repayments.

In order to determine the present value of costs (PVC) of electricity produced per year, the following research referred to in (Anon, 2011c; Vosburgh, 1983; Alnaser, 1993; Habali et al., 1987; Çetin et al., 2004) was used in this study as well:

$$
\begin{aligned}
P V C= & I+\operatorname{Com}\left(\frac{1+i}{r-i}\right) \\
& \times\left[1-\left(\frac{1+i}{1+r}\right)^{n}\right]-s\left(\frac{1+i}{1+r}\right)^{n}
\end{aligned}
$$

In order to determine the cost of wind turbine generation per $\mathrm{kWh}$ at different locations, two types of wind turbines have been chosen (as mentioned in Table 5).

\section{Discussion and results}

The results of this study consist of the change of wind speed value on basal sites, the energy production value of sites for each year with selected wind turbines, the energy production costs on basal sites and pay-back periods of investment.

The wind speed value changes between 19752010 for the Şile, Kumköy and Çorlu sites are shown in Figure 1. Wind speed was shown to have decreased every year in all sites. The statistical correlation of decreases in speed are given in Table 2 . The correlation coefficient was found to be 0.9225 for the Sile site. This is a high value for descending wind speed. The values were 0,625 for the Çorlu site and 0.3983 for the Kumköy site. These three locations were observed to determine the reasons for decreasing wind speed and urban structures were shown to be a determining factor across all sites. In conclusion, the reason for diminishing wind speed is not climatic - it is caused by urban structures in site locations.

Depending on the wind speed diminishing on all sites, the energy production value decreased with the chosen wind turbine. The energy production values of the Şile, Kumköy and Çorlu sites are shown in Figures 2, 3 and 4. The average of 36 years data, which was obtained from meteorology stations to calculate the energy production value with Nordex N117/2400 wind turbines of 91 - 140 $m$ hub height in Çorlu, Kumköy, Şile are 5984325,6 - 6351724,4 kWh/yr, 7205143,9 - 8110636,2 kWh/yr, 6.459.535 - 7430193,7 kWh/yr, respectively.

Although the energy production value decreased every year, there was an increase in 2007 
Table 3: Technical data of different wind machines

\begin{tabular}{lccccccccc}
\hline Wind Machine & $\begin{array}{c}\text { Cut-in } \\
\text { speed } \\
(\mathrm{ms}-1)\end{array}$ & $\begin{array}{c}\text { Cut-out } \\
\text { speed } \\
(\mathrm{ms}-1)\end{array}$ & $\begin{array}{c}\text { Rated } \\
\text { speed } \\
(\mathrm{ms}-1)\end{array}$ & $\begin{array}{c}\text { Tip } \\
\text { speed } \\
(\mathrm{ms}-1)\end{array}$ & $\begin{array}{c}\text { Rated } \\
\text { output } \\
(\mathrm{kW})\end{array}$ & $\begin{array}{c}\text { Hub } \\
\text { height } \\
(\mathrm{m})\end{array}$ & $\begin{array}{c}\text { Rotor } \\
\text { diameter } \\
(\mathrm{m})\end{array}$ & $\begin{array}{c}\text { Expected } \\
\text { life } \\
\text { (years })\end{array}$ \\
\hline Nordex N117/2400 & 3 & 20 & $7,5-13,2$ & 72 & 2400 & 91 & 116,8 & 20 \\
\hline Nordex N117/2400 & 3 & 20 & $7,5-13,2$ & 72 & 2400 & 140 & 116,8 & 20 \\
\hline
\end{tabular}

Table 4: Wind speed, power output, and kilowatt-hour for Kumköy for N117/2400 kW wind machine (at hub height $91 \mathrm{~m}$ ), Turkey

\begin{tabular}{|c|c|c|c|c|}
\hline $\begin{array}{l}\text { Wind speed } \\
\left(m s^{-1}\right)\end{array}$ & $\begin{array}{l}\text { Wind speed at } \\
\text { hub height }\left(\mathrm{ms}^{-1}\right)\end{array}$ & $\begin{array}{l}\text { No. of hours } \\
\text { per year }\end{array}$ & $\begin{array}{l}\text { Power output } \\
(k W)\end{array}$ & $\begin{array}{l}\text { Kilowatt-hour } \\
\text { (kWh) }\end{array}$ \\
\hline 0 & 0,0 & 76,7 & 0 & 0 \\
\hline 1 & 1,6 & 702,7 & 0 & 0 \\
\hline 2 & 3,3 & 1780,3 & 59,2 & 105395 \\
\hline 3 & 4,9 & 2054,3 & 332 & 682038 \\
\hline 4 & 6,5 & 1485,3 & 827 & 1228370 \\
\hline 5 & 8,1 & 940,7 & 1525 & 1434516 \\
\hline 6 & 9,8 & 582,3 & 2280 & 1327720 \\
\hline 7 & 11,4 & 386,3 & 2374 & 917155 \\
\hline 8 & 13,0 & 254,7 & 2400 & 611200 \\
\hline 9 & 14,7 & 160,3 & 2400 & 384800 \\
\hline 10 & 16,3 & 113,7 & 2400 & 272800 \\
\hline 11 & 17,9 & 78,0 & 2400 & 187200 \\
\hline 12 & 19,6 & 47,7 & 2400 & 114400 \\
\hline$\overline{13}$ & 21,2 & 33,0 & 0 & 0 \\
\hline 14 & 22,8 & 19,3 & 0 & 0 \\
\hline 15 & 24,4 & 7,0 & 0 & 0 \\
\hline 16 & 26,1 & 5,0 & 0 & 0 \\
\hline$\overline{17}$ & 27,7 & 5,0 & 0 & 0 \\
\hline 18 & 29,3 & 2,3 & 0 & 0 \\
\hline 19 & 31,0 & 0,0 & 0 & 0 \\
\hline 20 & 32,6 & 0,3 & 0 & 0 \\
\hline \multicolumn{4}{|c|}{ Power output per year $(\mathrm{kWh})=$} & 7.265 .597 \\
\hline
\end{tabular}

Table 5: Summary of cost (€/kWh) of wind power generation at 3 locations using two types of wind machines

\begin{tabular}{lcccc}
\hline $\begin{array}{c}\text { Location } \\
\text { Şile }\end{array}$ & $\begin{array}{c}\text { N117/2400-91m } \\
(\mathrm{kWh})\end{array}$ & $\begin{array}{c}\text { Cost } / \mathrm{kWh} \\
(\mathrm{US} \$ / \mathrm{kWh})\end{array}$ & $\begin{array}{c}\text { N117/2400-140m } \\
(\mathrm{kWh})\end{array}$ & $\begin{array}{c}\text { Cost } / \mathrm{kWh} \\
(\text { US } \$ / \mathrm{kWh})\end{array}$ \\
\hline Kumköy & 6459535.0 & 0.033 & 7430193.7 & 0.028 \\
\hline Çorlu & 7205143.9 & 0.025 & 8110636.2 & 0.022 \\
\hline
\end{tabular}

Table 6: Summary of pay-back period (year) of wind power generation at 3 locations using two types of wind turbines

\begin{tabular}{lcccc}
\hline $\begin{array}{c}\text { Location } \\
\text { S117/2400-91m income } \\
\text { (US\$/year)* }\end{array}$ & $\begin{array}{c}\text { Pay-back period } \\
\text { (year) }\end{array}$ & $\begin{array}{c}\text { N117/2400-140m income } \\
\text { (US\$/year)* }\end{array}$ & $\begin{array}{c}\text { Pay-back period } \\
\text { (year) }\end{array}$ \\
\hline Kumköy & 471545 & 9.0 & 542404 & 7.6 \\
\hline Çorlu & 530389 & 6.8 & 596779 & 6.0 \\
\hline
\end{tabular}

* To calculations of the value of power generation the price of per kWh is taken from EPDK (EMR, 2012) 0.073 US\$ 


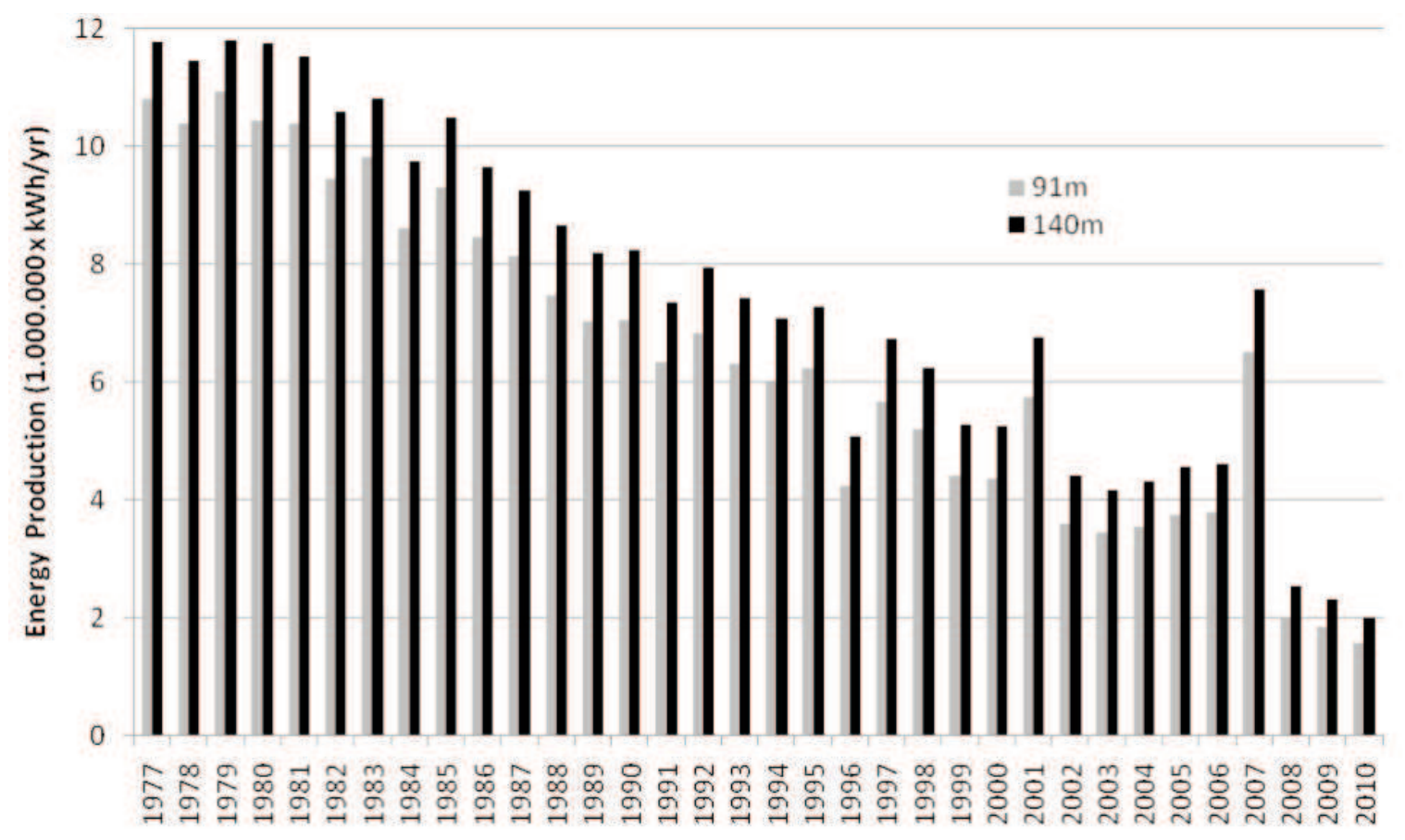

Figure 2: Energy production value with Nordex N117/2400 wind machine in Şile area

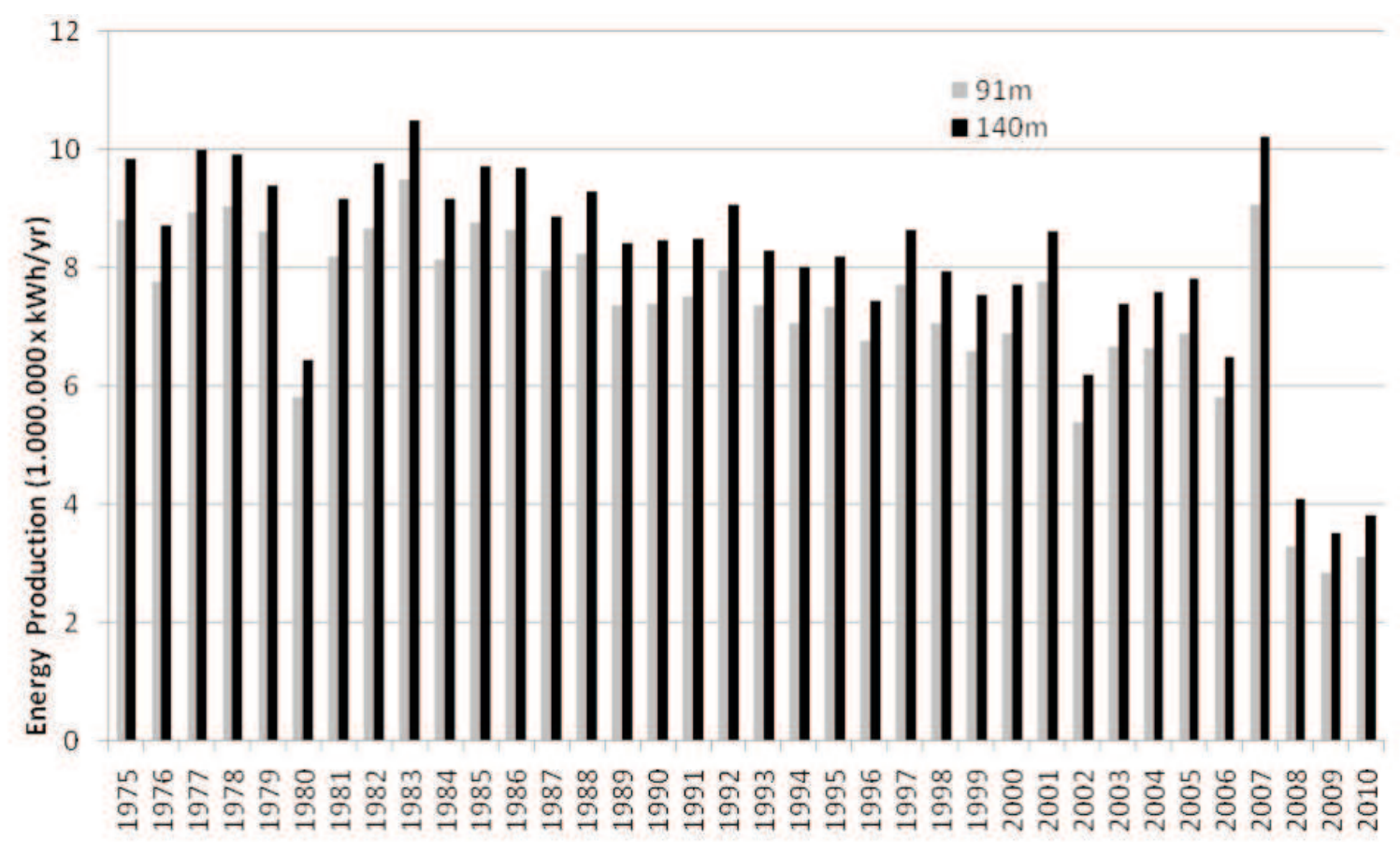

Figure 3: Energy production value with Nordex N117/2400 wind machine in Kumköy area

(Figure 4). The reason for the increase is global climate change and that particular year was the hottest year of the last century. It was an effect of global warming on wind speed.

The results of the economic analysis are shown in Table 5. The energy production costs with the wind turbine N117/2400 of $91 \mathrm{~m}$ hub height in Şile, Kumköy, Çorlu are 0,033 US \$/kWh, 0,025 US $\$ / \mathrm{kWh}, 0,03 \$ / \mathrm{kWh}$, respectively. Also, as seen in Table 5, the energy production costs with wind turbine $\mathrm{N} 117 / 2400$ of $140 \mathrm{~m}$ hub height in Şile,
Kumköy, Çorlu are 0.028 US \$/kWh, 0.022 US $\$ / \mathrm{kWh}, 0.028$ US $\$ / \mathrm{kWh}$, respectively.

The pay-back periods of Şile, Kumköy and Çorlu are shown in Table 6. According to these figures, the pay-back period of $91 \mathrm{~m}$ hub height N117/2400 wind turbine for Şile, Kumköy, Çorlu are 9, 6,8 and 8,2 years, respectively. The pay-back period of $140 \mathrm{~m}$ hub height $\mathrm{N} 117 / 2400$ wind turbine for Şile, Kumköy, Çorlu are 7.6, 6 and 7.7 years, respectively. 


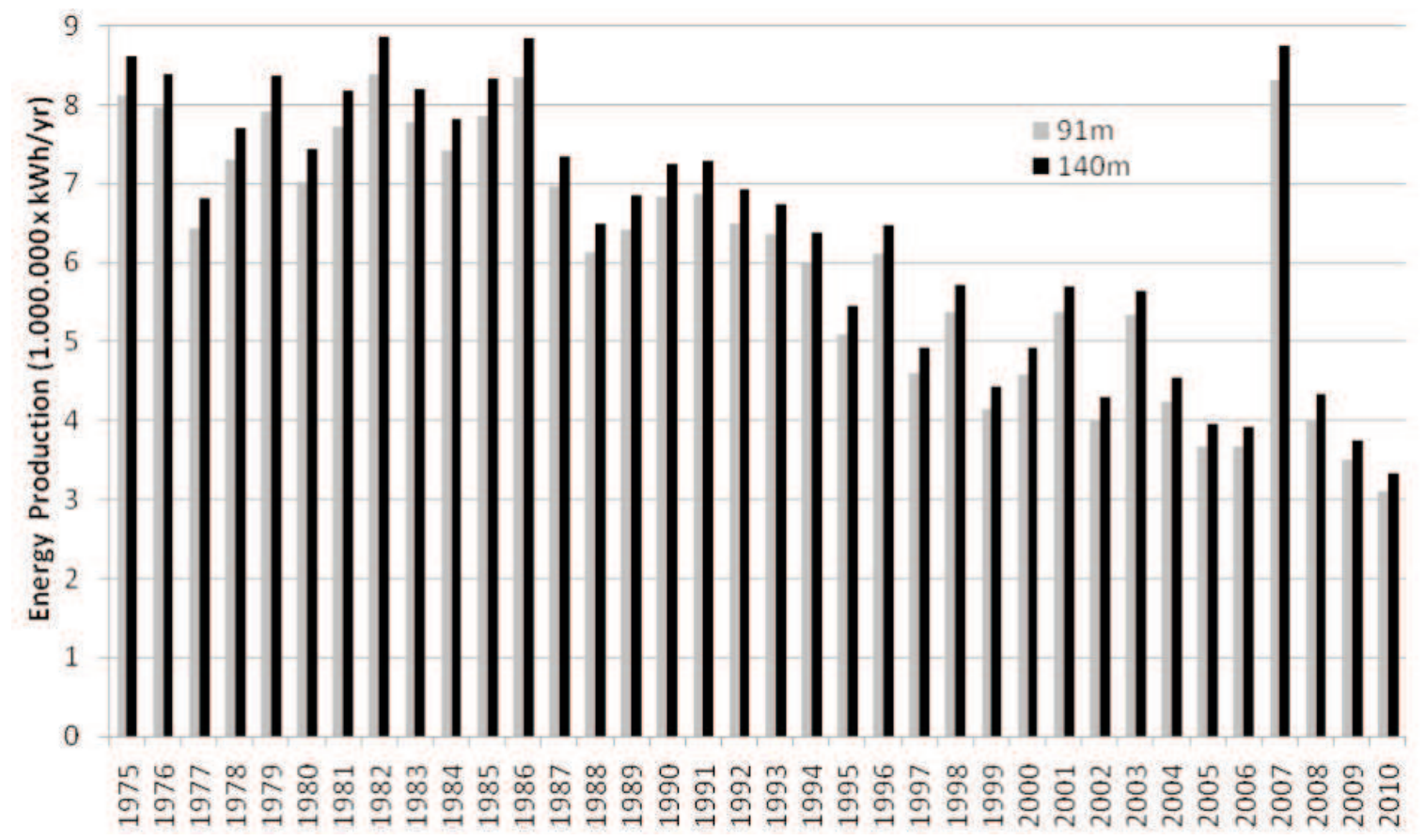

Figure 4: Energy production value with Nordex N117/2400 wind machine in Çorlu area

\section{Conclusion}

In this study, eight different locations in Istanbul were measured in terms of wind energy potential and wind characteristics. When the energy amount and cost was calculated, a 2.4 MW wind turbine was selected. The average of 36 years data which was obtained from meteorology stations to calculating the energy production value with a Nordex $\mathrm{N} 117 / 2400$ wind turbine on $91-140 \mathrm{~m}$ hub height in Çorlu, Kumköy, Şile are 5984325,6 - 6351724,4 $\mathrm{kWh} / \mathrm{yr}, \quad 7205143,9$ - 8110636,2 kWh/yr, 6.459.535 - 7430193,7 kWh/yr, respectively.

According to these results, the energy production costs calculated with a wind turbine N117/2400 on 91 m hub height in Şile, Kumköy, Çorlu are 0.033 US $\$ / k W h, 0.025$ US $\$ / k W h, 0.03$ $\$ / \mathrm{kWh}$, respectively. In addition, the energy production costs calculated with wind turbine N117/2400 on 140 m hub height in Şile, Kumköy, Çorlu are 0,028 US $\$ / \mathrm{kWh}, 0,022$ US $\$ / \mathrm{kWh}, 0,028$ US $\$ / k W h$, respectively. In the chosen locations, the pay-back period of $91 \mathrm{~m}$ hub height N117/2400 wind turbine in Şile, Kumköy, Çorlu was determined to be 9, 6,8, and 8,2 years, respectively, and the pay-back period of $140 \mathrm{~m}$ hub height $\mathrm{N} 117 / 2400$ wind turbine was determined to be 7.6, 6 and 7.7 years, respectively.

\section{Acknowledgements}

Because of their contributions to this study, we wish to thank the Turkish State Meteorological Service and Deanery of Agricultural Faculty of Uludag University. This study was funded by the Scientific Research Project Unit of Uludag University (Project No. Z-2013/31).

\section{References}

Alnaser W.E. (1993). Assessment of the possibility of using three types of wind turbine in Bahrain. Renewable Energy; 3 (2-3):179-184.

Anon (2011a). World Wind Energy Report 2010, World Wind Energy Association, Bonn, Germany.

Anon (2012b). Türkiye Rüzgar Enerjisi Tesis Bilgileri, Elektrik İşleri Etüt İdaresi Genel Müdürlüğü, Ankara. Web: http://www.eie.gov.tr/turkce/YEK/ruzgar/ Turkiye_RES.html, Aviable: 23 May 2012.

Anon (2011c). Turkish State Meteorological Organization. Web: http://www.mgm.gov.tr, Available: 23 May 2012.

Anon (2012d). Turkish Energy Market Regulatory Authority. Web: www.epdk.gov.tr, Avaible: 23 May 2012.

Çetin B, Yazgan S and Tipi T. (2004). Economics of drip irrigation of Olives in Turkey. Agricultural Water Management, 66 (2): 145-151.

Habali SM, Hamdan MAS, Jubran BA and Zaid A.I.O. (1987). Wind speed and wind energy potential of Jordan. Solar Energy 1987; 38 (1):59-70.

Kenisarin M, Karslı VM and Çağlar M., (2006). Wind power engineering in the world and perspectives of its development in Turkey. Renewable \& Sustainable Energy Reviews 2006; 10 (4): 341-369.

Orth, M., (2008). Rüzgarın gücü Enercon'un hikayesi, Deutschland Politika, kültür ve ekonomi forumu Say1: 2 sf. 40-46.

Vosburgh P.N. (1983). Commercial applications of wind power. Van Nostrand Reinhold Company, New York, NY.

Received 5 December 2013; revised 18 June 2015 